\title{
Scrub typhus-experience from a South Indian tertiary care hospital
}

\author{
MVS Subbalaxmi ${ }^{1 *}$, Naval Chandra', VD Teja ${ }^{2}$, Vemu Lakshmi ${ }^{2}$, MN Rao ${ }^{1}$, YSN Raju ${ }^{2}$ \\ From First International Science Symposium on HIV and Infectious Diseases (HIV SCIENCE 2012) \\ Chennai, India. 20-22 January 2012
}

\section{Background}

Scrub typhus, an emerging rickettsial disease caused by Orientia tsutsugamushi, is spread by the bite of larval trombiculid mites. The infection manifests as a febrile illness with diverse manifestations. This infection has to be differentiated from other tropical fevers. Our experience of 48 patients with scrub typhus admitted recently to our hospital is discussed.

\section{Methods}

Clinical features of 48 patients hospitalized between August and November 2011 with fever, positive OX-K Weil Felix test and clinically diagnosed as scrub typhus were analyzed. Patients with other established causes of fever were excluded.

\section{Results}

All these adult patients hailed from the rural Telangana region of Andhra Pradesh. Eighteen out of 48 were farmers. The average duration of fever was 11days. Eschar was noted in only $12.5 \%$ patients. Cough and breathlessness occurred in $30 \%$ cases. Central nervous system manifestations in the form of drowsiness and seizures were seen in 25\% cases. Signs of consolidation were seen in $40 \%$ of cases. Thrombocytopenia was seen in $37.5 \%$ patients. All patients had elevation of SGOT and SGPT, while 52\% patients had elevation of serum alkaline phosphatase. Acute renal failure was seen in $33 \%$ patients. $10.4 \%$ patients required mechanical ventilation and6.25\% died of multiorgan failure.

\section{Conclusion}

Scrub typhus needs to be considered as an important differential diagnosis in febrile patients with elevated

\footnotetext{
* Correspondence: subbalaxmimvs@gmail.com

'Department of General Medicine, Nizam's Institute of Medical Sciences, Hyderabad, India

Full list of author information is available at the end of the article
}

liver enzymes. Complete response with doxycycline was observed in $93.75 \%$ cases. Early diagnosis and appropriate treatment will prevent morbidity and mortality.

\section{Author details}

'Department of General Medicine, Nizam's Institute of Medical Sciences, Hyderabad, India. '2Department of Microbiology, Nizam's Institute of Medical Sciences, Hyderabad, India.

Published: 4 May 2012

doi:10.1186/1471-2334-12-S1-P77

Cite this article as: Subbalaxmi et al:: Scrub typhus-experience from a South Indian tertiary care hospital. BMC Infectious Diseases 2012 12(Suppl 1):P77.
Submit your next manuscript to BioMed Central and take full advantage of:

- Convenient online submission

- Thorough peer review

- No space constraints or color figure charges

- Immediate publication on acceptance

- Inclusion in PubMed, CAS, Scopus and Google Scholar

- Research which is freely available for redistribution

Submit your manuscript at www.biomedcentral.com/submit

\section{() Biomed Central}

C Biomed Central

C 2012 Subbalaxmi et al; licensee BioMed Central Ltd. This is an Open Access article distributed under the terms of the Creative Commons Attribution License (http://creativecommons.org/licenses/by/2.0), which permits unrestricted use, distribution, and reproduction in any medium, provided the original work is properly cited. 